\title{
The Influence of Empowerment, Society Culture And Level Education Of Head Poor Household Towards Social Capital And Accessibility of Information And The Impact For Welfare OF Poor Household in Batam City of Kepulauan Riau Province
}

\author{
Syahril Effendi \\ University doctoral student, August 17, 1945, Surabaya, Indonesia \\ Ujianto \\ University lecturer, August 17, 1945 Surabaya, Indonesia \\ Sunu Priyawan \\ University lecturer, August 17, 1945, Surabaya, Indonesia
}

\begin{abstract}
The Government's policy for tackling poverty both national and regional interests can be done start with the creation of new jobs, increased educational programs and skills, to the implementation of the programs like presidential instruction Village left behind, the establishment of family welfare Savings, cooperative efforts of family welfare, until Social Security Nets Project, Sub Development Program and others. Households living with many members with the head of household who can potentially lower degree kids will face a higher poverty risk than others. This research aims to demonstrate and analyze the influence of empowerment, society culture and level education of head poor household towards social capital and accessibility of information and the impact for welfare of poor household in Batam City of Kepulauan Riau Province. The population in the research this is 36.103 head poor household in Batam City of Kepulauan Riau Province and the sample numbered 244 people. This research uses of data analysis in SEM (Structure Equational Modeling) using the AMOS version 22. The results of the discussions can be concluded that community empowerment effect significantly to social capital, community empowerment effect significantly to accessibility of information, community empowerment not significant effect against The welfare of $\mathrm{PH}$ in Batam city, popular culture has no effect significantly to social capital, cultural Society has no effect significantly to information accessibility, society culture has no effect significantly to The welfare of the $\mathrm{PH}$, PH Head influential Education Levels significantly to social capital in Batam city, education level of the head of the PH effect significantly to information accessibility PH, PH Head education level have no effect in significantly to the well-being of PH in Batam city, social capital has no effect against the welfare of the $\mathrm{PH}$ and the accessibility of information to the welfare of the PH. The Influence of Empowerment, Society Culture and Level Education of Head Poor Household Towards Social Capital and Accessibility of Information and The Impact For Welfare of Poor Household in Batam City of Kepulauan Riau Province.
\end{abstract}

Keywords: empowerment, society culture, Level Education of Head PH, social capital, accessibility of information and welfare

\section{INTRODUCTION}

Households that are experiencing absolute poverty are in a situation of chronic hunger, unable to access health facilities, do not have a source of clean water and good sanitation, not being able to send a portion or all of the children in the household and may not have basic shelter. (BPS, 2008:5). Lewis (1998), noted for tackling poverty improvements and changes the structure of the societal need to get attention because in the structure of society has a culture 
Effendi, S., Ujianto., \& Priyawan, S. (2018). The Influence Of Empowerment, Society Culture And Level Education Of Head Poor Household Towards Social Capital And Accessibility Of Information And The Impact For Welfare OF Poor Household in Batam City of Kepulauan Riau Province. Archives of Business Research, 6(4), 215-223

that is reflected in the form of values and norms that lead to the behavior of the so-called culture of poverty.

The culture of poverty is an adaptation or adjustment and reaction of the poor against the position of their marginal in society. Poor people have a habit of yourself with different community mostly. Such a negative attitude: lazy, fatalism or succumbed to fate, feelings of worthlessness, helplessness, dependency and a sense of inferiority, don't have the soul of entrepreneurship and less respect for the work ethic. Attitude taken a household will give an impact on culture.

Gustafson and Yue (2006) conclude a lively household with many members with the head of a household that his education is low then the children face a higher poverty risk than others. Households have family members more than 4 people have opportunities 1.312 times more likely to be poor with education of household head JUNIOR down. Up to this point has many steps undertaken by the Government to tackle poverty is either national or regional. Start of the activities of the new job creation, increased educational programs and skills, to the implementation of programs such as the presidential instruction of the village left behind, establishment of family welfare Savings, cooperative Family welfare efforts, comes to the project of Social Security Net, Sub Development Program and others.

Batam City Government has done a variety of efforts to tackle poverty through various poverty alleviation programs, such as economic empowerment of poor families through the granting of economic aid productive group joint venture (KUBE) is a procurement tool to catch fish to the fisherman in Batam city. This effort can absorb much manpower. Pro active role of Government and society in Batam city not optimal encourage poverty reduction program in the movement towards social welfare because not done on integrated in the main perspectives home communities prosper the stairs are poor. Poverty reduction will become more focused by using a pattern of community empowerment.

Contradictions of this research with previous research Purwanti (2010) that the outpouring of work, poor households are less significant results towards poverty reduction; Nugroho (2015) stated that, venture capital poor households: owned assets, development opportunities, and venture capital management capital development effort acceptability has not been giving influence on economic increase in revenue Community; Qodriyatun (2013) that, not all successful community empowerment program empowers poor households Batam city.

The active role of the Government and the community in Batam city not optimal economic push poor households, because it emphasizes the focus on perspectives and expectations for poor households. Community empowerment is exercised without any breakthrough and tend to follow the previous activities. Planning and less-active program involves the community, as well as the implementation, have not had a significant impact on quality of life and prosperity for poor households in Batam city. Based on the explanation on the background, then the researchers lifted the title of the dissertation "The Influence of Empowerment, Society Culture and Level Education of Head Poor Household Towards Social Capital and Accessibility of Information and The Impact For Welfare of Poor Household in Batam City of Kepulauan Riau Province". 


\section{Community Empowerment}

\section{LITERATURE REVIEW AND HYPOTHESIS}

Community empowerment can provide access to the communities, institutions and community organizations with acquiring and utilizing the right community for improved quality of life, because the cause of the powerlessness of society caused by limitations of access, lack of knowledge and skills as well as the existence of conditions of poverty experienced by most people (Suhartini, et al, 2005). Suharto (2006) see the dimensions are (a) meets the needs of not only the non suggested, but rather free from hunger, freedom from ignorance, freedom from pain (b) concerns the productive resources which allow they can improve the income and obtain goods and services that they need, and (c) participate in the development process and the decisions that affect them.

\section{Level Education of PH}

Asriani (2011) said that Education is a basic human needs in order to meet the spiritual needs and the power of his reason which is equivalent to the other principal needs to meet physical needs and social mental. Spiritual needs and physical needs is basic human needs that must be met, so it is difficult and expensive the price of education must be met by the country in sufficient basic necessities its citizens. Education became a major key to success of a nation, to bring about the well-being and prosperity of its people (Dario: 2013). A good nation is a nation that pays attention to and build a good education system. If a country has not been able to develop the education system is good then the country hasn't been able to reach the prosperity that occurred in the country the smart, affluent and prosperous, such as; Japan, South Korea, United Kingdom, Germany, the United States, Canada, Australia and so on.

\section{Social Capital}

Putnam, et al (2007) social capital is the appearance of social organization, such as trust, norms (or reciprocity), and network (from the bonds of the community), which can improve the efficiency of the community by facilitate the existence of coordination and cooperation for mutual benefit. Fukuyama (1995) States of social capital is a capability that arises from the existence of the trust in a community. Suharto's (2007) social capital can be treated as an accumulation of various types of psychological, social, cultural, institutional, and immeasurable assets associated influences the behavior of cooperation. Hasbullah (2006) there are six principal elements in social capital based on the various notions of social capital, namely: (1) participation in a network, (2) reciprocity, (3) trust, (4) social norms, (5) values, and (6) proactive actiony.

\section{Accessibility Information}

Accessibility of information has now become a basic necessity for human beings. Information into basic device used one to know everything in terms of development potential of himself in all aspects of life. Freedom of information access was supposed to be the rights of the citizen guaranteed by the Constitution of the Republic of Indonesia year 1945 (UUD 1945). Digitization promises effectiveness of frequency that initially only one channel per channel, into twelve channels per channel. Even the music and movie industry despite highly susceptible piracy, now can be more cost-saving production with a digital system. The good news as well as profit doubled makes digitizing to trending. The digitization era even offers a new solution to realize the diversity of content, diversity of ownership, and the freedom of speech for all citizens.

\section{Welfare of Society}

The welfare of society is a condition that shows about the State of public life which can be seen from the standards of public life (Badrudin, 2012). Todaro and Smith (2006), community 
welfare development results indicate the size of the community in attaining a better life which include: first, the improvement of the ability and equitable distribution of basic needs such as food, housing, health care and protection. Second, the increase in the level of life, level of income, better education and increased attention to culture and human values; and third, expand the scale of economic and social options availability of individuals and Nations. The legislation of the Republic of Indonesia number 11 year 2009 social welfare is a condition of material needs, satisfy the spiritual and social life of the citizen in order to be variable and able to develop themselves, so that it can carry out its social function, and organizing social welfare efforts are focused, integrated, and sustainable Government, local government and the community in the form of social services to meet the basic needs of every citizen, which includes social rehabilitation, social security, social empowerment, and social protection.

\section{Research Hypothesis}

1. Empowerment effect significantly to social capital.

2. Empowerment effect significantly to accessibility of information.

3. Empowerment significant effect against the welfare in Batam city.

4. Society cultural effect significantly to social capital.

5. Society cultural effect significantly to accessibility of information.

6. Society cultural effect significantly to the welfare.

7. Level of education of the head PH effect significantly to social capital in batam city.

8. Level of education of the head PH effect significantly to accessibility of information.

9. Level of education of the head PH effect significantly to the well-being of PH in Batam city.

10. Social capital has no effect against the welfare.

11. The accessibility of information effect significantly to the welfare.

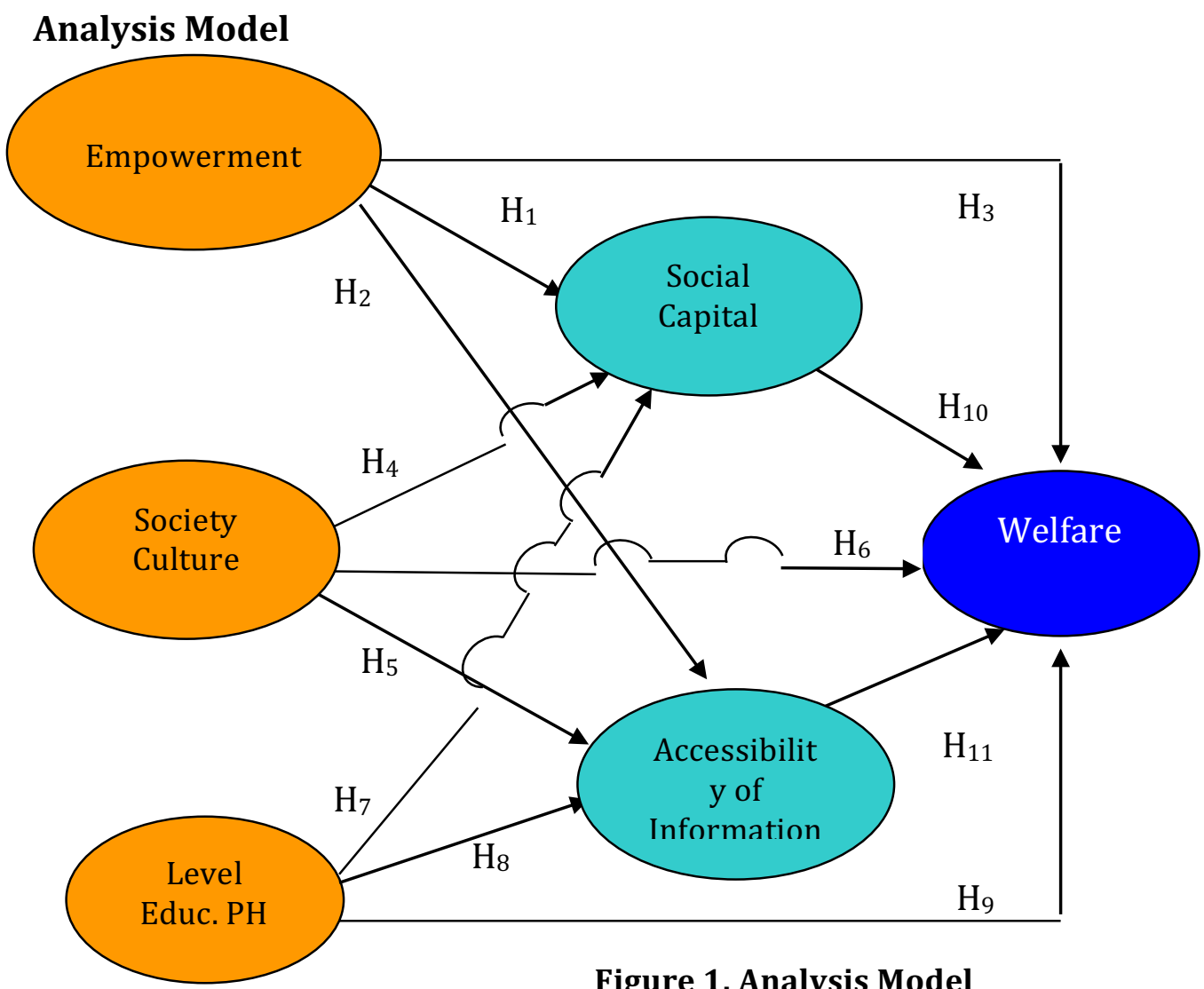

Figure 1. Analysis Model 


\section{RESEARCH METHODS}

The primary data was collected from questionnaires which filled by poor households in Batam city. Respondents where asked to answer or select one of the numbers form to 1 to 5 scale (Scale liked) according to their expectations or thoughts which is appropriate with the filled condition. The population in this research is 36.103 poor households in Batam city of Kepulauan Riau Province. The number of samples obtained on the basis of 244 poor households. Measurement techniques questionnaire using likert scale. This research uses of data analysis in SEM (Structure Equational Modeling) using the AMOS version 22 (Ferdinand ,2002: 40).

\section{ANALYSIS AND DISCUSSION}

The results show that all goodness of fit criteria have given a fit index. Furthermore, it will be followed by testing the reliability of SEM model and hypothesis testing. The results of the analysis of the relationship of causality between the variables research using program AMOS version 22 can be seen in table 1.

Tabel 1. Evaluation Criteria Goodness of Fit Indices

\begin{tabular}{|l|c|c|l|}
\hline \multicolumn{1}{|c|}{ Goodness of fit measure } & Indeks & Cuf off & Explanation \\
\hline Chi-Square of estimate model & 445,957 & & \\
\hline Probability level & 0,000 & $>0,050$ & Marginal \\
\hline DF & 1,914 & $\geq 2,000$ & Fit model \\
\hline Goodness of Index (GFI) & 0,876 & $\geq 0,900$ & Marginal \\
\hline $\begin{array}{l}\text { Adjusted goodness of index } \\
\text { (AGFI) }\end{array}$ & 0,927 & $\geq 0,900$ & Fit model \\
\hline RMSEA & 0,061 & $\leq 0,080$ & Fit model \\
\hline Tucker-Lewis Index (TLI) & 0,930 & $\geq 0,900$ & Fit model \\
\hline Comparative fit Index (CFI) & 0,946 & $\geq 0,900$ & Fit model \\
\hline
\end{tabular}

Testing the hypothesis presented in this study was done based on the value of the Critical ratio of CR from a relationship of causality. The results of the analysis of the relationship of causality between the variables research using program AMOS version 22 can be seen in table 2 .

Table 2. Test Causality Regression Weight

\begin{tabular}{|ccc|c|c|c|}
\hline \multicolumn{2}{|c|}{ The Relationship of Causality } & C.R & P Value & Explanation \\
\hline Empowerment & $\rightarrow$ & Social Capital & 3,413 & 0,000 & Significant \\
\hline Empowerment & $\rightarrow$ & $\begin{array}{c}\text { Accessibility of } \\
\text { Information }\end{array}$ & 2,767 & 0,006 & Significant \\
\hline Empowerment & $\rightarrow$ & Welfare & 0,565 & 0,572 & Not Significant \\
\hline Society Culture & $\rightarrow$ & Social Capital & 0,385 & 0,700 & Not Significant \\
\hline Society Culture & $\rightarrow$ & $\begin{array}{c}\text { Accessibility of } \\
\text { Information }\end{array}$ & 0,860 & 0,390 & Not Significant \\
\hline Society Culture & $\rightarrow$ & Welfare & 0,927 & 0,354 & Not Significant \\
\hline Level Educ. PH & $\rightarrow$ & Social Capital & 11,167 & 0,000 & Significant \\
\hline Level Educ. PH & $\rightarrow$ & $\begin{array}{c}\text { Accessibility of } \\
\text { Information }\end{array}$ & 5,741 & 0,000 & Significant \\
\hline Level Educ. PH & $\rightarrow$ & Welfare & 0,739 & 0,460 & Not Significant \\
\hline Social Capital & $\rightarrow$ & Welfare & 0,817 & 0,414 & Not Significant \\
\hline $\begin{array}{c}\text { Akses } \\
\text { Informasi }\end{array}$ & $\rightarrow$ & Welfare & 3,147 & 0,002 & Significant \\
\hline
\end{tabular}




\section{Empowerment effect significantly to social capital}

Based on the results of confirmatory factor analysis, indicators of the level of ability to build cooperation and solidarity contributes the highest among other indicators towards the empowerment of the variable poor households shown with the value of the loading factor of 0.943. While the indicators of competitiveness strong contributes the highest among other indicators against Social Capital variables indicated by the value of loading factor of 0.848 . Based on the results of hypothesis testing, proving that the empowerment of PH has significant effects against social capital.

\section{Empowerment effect significantly to accessibility of information}

Based on the results of confirmatory factor analysis, indicators of the level of ability to build cooperation and solidarity (power with) contributes the highest among other indicators towards the empowerment of the variable PH shown with the value of the loading factor of 0.943. While the indicators about the Increasing flow of information contributes the highest among other indicators against variable Accessibility information that is indicated by the value of the loading factor of 0.894 . Based on the results of hypothesis testing, proving that the empowerment of PH has significant effects against Accessibility Information.

\section{Empowerment effect significantly to welfare in Batam city}

Based on the results of confirmatory factor analysis, indicators of the level of ability to build cooperation and solidarity contributes the highest among other indicators towards the empowerment of the variable PH shown with the value of the loading factor of 0.943 . While the indicators about the Increasing flow of information contributes the highest among other indicators against variable Accessibility information that is indicated by the value of the loading factor of 0.894. Based on the results of hypothesis testing, proving that the empowerment of PH has significant effects against accessibility of information.

\section{Society cultural effect significantly to social capital}

Based on the results of confirmatory factor analysis, indicators of the level of ability to build cooperation and solidarity contributes the highest among other indicators towards the empowerment of the variable poor households shown with the value of the loading factor of 0.943. While the indicators on Education exceed compulsory education from the Government contributes the highest among other indicators of welfare variables against poor households, indicated by the value of the loading factor of 0.826 . Based on the results of hypothesis testing, proving that Empowerment does not have significant influence towards the welfare of the PH.

\section{Society cultural effect significantly to accessibility of information}

Based on the results of confirmatory factor analysis, indicators about the influence of the values that exist in the community contributes the highest among other indicators against the $\mathrm{PH}$ Community Cultural variables indicated by the value of loading factor of 0.922 . While the indicators of competitiveness strong contributes the highest among other indicators against Social Capital variables indicated by the value of loading factor of 0.848 . Based on the results of hypothesis testing, proving that popular culture is not PH has significant effects against social capital.

\section{Society cultural effect significantly to the welfare in Batam}

Based on the results of confirmatory factor analysis, an indicator of the influence of the values that exist in the community contributes the highest among other indicators against the $\mathrm{PH}$ Community Cultural variables indicated by the value of loading factor of 0.922 . While the 
indicators about the Increasing flow of information contributes the highest among other indicators against variable Accessibility information that is indicated by the value of the loading factor of 0.894. Based on the results of hypothesis testing, proving that popular culture is not PH has significant effects against accessibility information.

\section{Influence of level education head poor households to social capital}

Based on the results of confirmatory factor analysis, indicators of primary and Secondary Schools and certified by the first (9-year compulsory education) contributes the highest among other indicators against a variable level of education the PH Head indicated by the value of the loading factor of 0.872 . While the indicators of competitiveness strong contributes the highest among other indicators against Social Capital variables indicated by the value of loading factor of 0.848 , based on the results of hypothesis testing, proving that The education level of the head of the PH has significant effects against social capital.

\section{Influence of educational level head poor households to accessibility of information}

Based on the results of confirmatory factor analysis, indicators of primary and Secondary Schools and certified by the first (9-year compulsory education) contributes the highest among other indicators against a variable level of education the PH Head indicated by the value of the loading factor of 0.872 . While the indicators about the Increasing flow of information contributes the highest among other indicators against variable Accessibility information that is indicated by the value of the loading factor of 0.894 . Based on the results of hypothesis testing, proving that education level of the head of $\mathrm{PH}$ has significant effects against Accessibility information.

\section{Influence of educational level head poor households to the welfare in Batam}

Based on the results of confirmatory factor analysis, about primary and Secondary Schools and certified by the first (9-year compulsory education) contributes the highest among other indicators against a variable level of education head of PH which indicated with the value of the loading factor of 0.872. While the Educational indicators exceed compulsory education from the Government contributes the highest among other indicators of welfare variables against $\mathrm{PH}$, indicated by the value of the loading factor of 0.826 . Based on the results of hypothesis testing, proving that the education level of the head $\mathrm{PH}$ does not have significant influence towards the welfare of the PH.

\section{Influence of social capital to the welfare in Batam}

Based on the results of confirmatory factor analysis, indicators of primary and Secondary Schools and certified by the first (9-year compulsory education) contributes the highest among other indicators against Social Capital variables shown with loading factor value of 0.848 . While the indicators on Education exceed compulsory education from the Government contributes the highest among other indicators of welfare variables against $\mathrm{PH}$, indicated by the value of the loading factor of 0.826 . Based on the results of hypothesis testing, proving that social capital does not have significant influence towards the welfare of the PH.

\section{Influence of information accessibility to welfare}

Based on the results of confirmatory factor analysis, indicators about the Increasing flow of information contributes the highest among other indicators against variable Accessibility information that is indicated by the value of the loading factor of 0.894 . While the indicators on Education exceed compulsory education from the Government contributes the highest among other indicators of welfare variables against $\mathrm{PH}$, indicated by the value of the loading factor of 0.826. Based on the results of hypothesis testing, proving that Accessibility of information have significant influence towards the welfare of the PH. 


\section{SUMMARY}

1. Empowerment effect significantly to social capital.

2. Empowerment effect significantly to accessibility of information.

3. Empowerment not significant effect against the welfare in Batam city.

4. Society cultural has no effect significantly to social capital.

5. Society cultural has no effect significantly to accessibility of information.

6. Society cultural has no effect significantly to the welfare in Batam.

7. Level education of head poor households effect significantly to social capital in Batam city.

8. Level education of head poor households effect significantly to accessibility of information.

9. Level education of head poor households no effect significantly to welfare in Batam city.

10. Social capital has no effect against the welfare.

11. Accessibility of information have significant influence towards the welfare in Batam.

\section{LIMITATIONS}

1. The Government of Batam city are advised to create a policy of equitable development for more fair for the town has the largest PH.

2. The role and contribution of non-governmental organizations (NGOS) which is a viable organization beyond a Government. Included in the $\mathrm{PH}$ the most data validation updates. and the problem of data its accuracy can be maintained should the PH.

3. Loan Revolving Fund is one of the options from a wide range of alternative activities to tackle poverty. The principle of management of revolving loan funds utilization of $100 \%$ should be poor residents listed in list of $\mathrm{PH}$ and should be harnessed for the benefit of earning can increase income and welfare or the PH.

4. Do the next research development with a research sample number of PH which is more rational.

5. Perform the next research development with data validation that supported more accurate and factual.

\section{BIBLIOGRAPHY}

.2004. Law Number 32 year 2004 About the autonomy of the region. 2000. Law number 25 year 2000 about Propenas.

2009. Law Number 32 Year 2009 on the protection and management of the environment as well as the explanation.

Afandi, W.N. 2011. The Identification of the Characteristics of poor households in Padang Pariaman (case study of Nagari Malai V Tribe)". Thesis. Faculty Of Economics, Andalas of University.

Azwar, s. 2005. Human attitude theory and Measurement. Yogyakarta: Liberty

Aziz, U. 2006. The Characteristics of Poverty and its effects on the conditions of Poverty in North Sumatra. Journal Of Economic Policy. The University Of Indonesia, Jakarta.

Dinar, B. 2008. The Social Analysis of household Economic Relation with poverty in the countryside: a case study in Central Tapanuli Regency, Green Rides. Vol. 4 No. 1.

Ferdinand, A. 2002. Structural Education Modelling in research management. The first edition. Semarang: Diponegoro of University.

Firmansyah, Hairi. 2012. The level of the Keberdayaan community in the community empowerment Program in the city of Banjarmasin and district land sea. Journal of Rural Agribusiness. Volume 02 Number 01 March 2012. Lambung Mangkurat.

Lewis, Oscar. 1988. The story of five families. Review-review cases of people in Mexico the culture of poverty. Jakarta: Yayasan Obor Indonesia. 
Suharto, Edi. 2009. Community building and empowering People: the study of the Strategic Development social and Welfare Social Work. Bandung: Rafika Aditama

Suartha, N. 2012. Influence the capacity of Households, culture and attitude towards Empowerment and Welfare poor households in Karangasem Regency of Bali. Dissertation.

Todaro. 2004. Economic development. Yogyakarta: Gadjah Mada University BPFE. 